\title{
Benzothiadiazine Suppression of Insulin Release from Normal and Abnormal Islet Tissue in Man*
}

\author{
Stefan S. Fajans, † John C. Floyd, Jr., Ralph F. Knopf, Juan Rull, \\ EnRique M. Guntsche, and Jerome W. Conn \\ (From the Department of Internal Medicine, Division of Endocrinology and Metabolism and \\ the Metabolism Research Unit, the University of Michigan, Ann Arbor, Mich.)
}

The diabetogenic activity of benzothiadiazine drugs has been well established (2). Diazoxide ${ }^{1}$ is an antihypertensive agent with potent hyperglycemic activity, particularly when used in combination with trichlormethiazide ${ }^{2}(3-5)$. The mode of action by which these compounds exert a temporary diabetogenic effect has not been established. It has been suggested by some that diazoxide-induced hyperglycemia may result from inhibition of insulin release. Samaan, Dollery, and Fraser found that insulin-like activity (both "typical" and "atypical") as measured by the epididymal fat pad technique was lower in four diabetic patients taking thiazides than in normal subjects (6). Within 3 to 26 weeks after thiazides were discontinued, insulin-like activity rose, but the levels still remained below those of normal subjects. Wolff has suggested that diazoxide blocks release of insulin, since the hyperglycemic action of diazoxide was diminished or abolished by simultaneous administration of tolbutamide to experimental animals $(7,8)$.

On the other hand, the following evidence has been presented to indicate that benzothiadiazineinduced hyperglycemia is not mediated through inhibition of insulin release: $a$ ) diazoxide elicits a hyperglycemic effect in surgically depancreatized

* Submitted for publication September 13, 1965; accepted December 16, 1965.

Presented in part at the Forty-seventh Annual Meeting of the Endocrine Society, New York, N. Y., June 17-19, 1965 (1).

Supported in part by U.S. Public Health Service grants AM 02244, AM 00888, 2A-5001, National Institute of Arthritis and Metabolic Diseases, and 5M01-FR-42-05, Division of Research Facilities and Resources.

$\dagger$ Address requests for reprints to Dr. Stefan S. Fajans, University Hospital, University of Michigan Medical Center, Ann Arbor, Mich. 48104.

1 3-Methyl-7-chloro-1,2,4-benzothiadiazine-1;1-dioxide.

2 3-Dichloromethyl-6-chloro-7-sulfamyl-3, 4-dihydro-1,24-benzothiadiazine-1, 1-dioxide. dogs $(9), b)$ plasma levels of insulin-like activity do not decrease in normal or diabetic subjects (10), or in rats (11) made hyperglycemic by administration of diazoxide, and $c$ ) in patients with metastatic insulin-secreting tumors, the hyperglycemic response to diazoxide and other benzothiadiazines occurs without apparent reduction in plasma levels of insulin $(12,13)$. Other additional evidence has been presented to indicate that diazoxide hyperglycemia is an extrapancreatic phenomenon $(9,11)$.

We $(14,15)$ have shown that when leucine is given to chlorpropamide ${ }^{3}$-pretreated healthy subjects hypoglycemia together with a sharp increase in plasma insulin occurs. We have also shown that increased release of insulin from the pancreatic beta cells is the mechanism by which leucine increases peripheral levels of insulin (16). In the studies described below we have determined the effects of trichlormethiazide and diazoxide in combination upon levels of blood glucose and plasma

TABLE I

Experimental design of benzothiadiazine-leucine study in healthy subjects

\begin{tabular}{|c|c|c|c|c|c|c|}
\hline Day & $\begin{array}{l}\text { Chlor- } \\
\text { prop- } \\
\text { amide* }\end{array}$ & $\begin{array}{l}\text { Tri- } \\
\text { chlor- } \\
\text { methi- } \\
\text { azide* }\end{array}$ & $\begin{array}{l}\text { Infusion I over } 60 \\
\text { minutes }\end{array}$ & $\rightarrow \leftarrow$ & \multicolumn{2}{|c|}{$\begin{array}{c}\text { Infusion II over } \\
30 \text { minutest }\end{array}$} \\
\hline & $g$ & $m g$ & & & & \\
\hline 1 & 1.0 & & & & & \\
\hline 2 & 0.5 & & & & & \\
\hline 3 & 0.5 & & & & & \\
\hline 4 . & 0.5 & 6 & $300 \mathrm{ml}$ saline & & Leucine & (S-L \\
\hline 5 & 0.5 & 8 & . & & & \\
\hline 6 & 0.5 & 10 & $\begin{array}{l}300 \mathrm{ml} \text { saline } \\
+600 \mathrm{mg} \text { diazoxide }\end{array}$ & & Leucine & (T-D-L \\
\hline 7 & & 10 & $\begin{array}{l}300 \mathrm{ml} \text { saline } \\
\quad+600 \mathrm{mg} \text { diazoxide }\end{array}$ & & Saline & (T-D-S) \\
\hline
\end{tabular}

* Administered orally

† S-L = saline-leucine, T-D-L = trichlormethiazide-diazoxide-leucine and $T-D-S=$ trichlormethiazide-diazoxide-saline, tests.

\footnotetext{
3 1-Propyl-3 ( $p$-chlorobenzenesulfonyl) urea.
} 
Levels of blood glucose and plasma insulin after infusion of leucine to chlorpropamide-

\begin{tabular}{|c|c|c|c|c|c|c|c|c|c|c|c|c|c|c|c|c|c|c|c|c|c|c|}
\hline \multirow{2}{*}{$\begin{array}{c}\text { Sub- } \\
\text { ject }\end{array}$} & \multirow[b]{2}{*}{ Test* } & \multicolumn{21}{|c|}{ Blood glucose at time in minutes } \\
\hline & & -61 & -60 & -45 & -30 & -15 & 0 & 10 & 20 & 30 & 40 & 50 & 60 & 75 & 90 & 105 & 120 & 130 & 140 & 150 & 165 & 180 \\
\hline & & \multicolumn{21}{|c|}{$\mathrm{mg} / 100 \mathrm{ml}$} \\
\hline G.M. & $\begin{array}{l}\text { S-L } \\
\text { T-D-L } \\
\text { T-D-S }\end{array}$ & $\begin{array}{l}81 \\
91 \\
88\end{array}$ & $\begin{array}{l}83 \\
92 \\
94\end{array}$ & $\begin{array}{l}84 \\
94 \\
99\end{array}$ & $\begin{array}{r}85 \\
99 \\
107\end{array}$ & $\begin{array}{r}84 \\
110 \\
111\end{array}$ & $\begin{array}{r}86 \\
111 \\
116\end{array}$ & $\begin{array}{r}82 \\
114 \\
115\end{array}$ & $\begin{array}{r}77 \\
106 \\
116\end{array}$ & $\begin{array}{r}68 \\
111 \\
112\end{array}$ & $\begin{array}{r}55 \\
116 \\
112\end{array}$ & $\begin{array}{r}44 \\
119 \\
111\end{array}$ & $\begin{array}{r}36 \\
121 \\
115\end{array}$ & $\begin{array}{r}42 \\
124 \\
116\end{array}$ & $\begin{array}{r}55 \\
119 \\
116\end{array}$ & $\begin{array}{r}70 \\
118 \\
117\end{array}$ & $\begin{array}{r}78 \\
117 \\
115\end{array}$ & & & $\begin{array}{r}85 \\
123 \\
118\end{array}$ & & \\
\hline B.E. & $\begin{array}{l}\text { S-L } \\
\text { T-D-L } \\
\text { T-D-S }\end{array}$ & $\begin{array}{l}79 \\
82 \\
87\end{array}$ & $\begin{array}{l}88 \\
86 \\
91\end{array}$ & $\begin{array}{l}86 \\
89 \\
94\end{array}$ & $\begin{array}{l}88 \\
96 \\
98\end{array}$ & $\begin{array}{r}85 \\
98 \\
103\end{array}$ & $\begin{array}{r}86 \\
102 \\
105\end{array}$ & $\begin{array}{r}83 \\
99 \\
103\end{array}$ & $\begin{array}{r}75 \\
95 \\
103\end{array}$ & $\begin{array}{r}66 \\
92 \\
102\end{array}$ & $\begin{array}{r}56 \\
92 \\
101\end{array}$ & $\begin{array}{r}50 \\
90 \\
100\end{array}$ & $\begin{array}{r}47 \\
98 \\
102\end{array}$ & $\begin{array}{r}60 \\
97 \\
104\end{array}$ & $\begin{array}{r}67 \\
96 \\
103\end{array}$ & $\begin{array}{r}72 \\
97 \\
102\end{array}$ & $\begin{array}{r}77 \\
96 \\
104\end{array}$ & & & $\begin{array}{r}79 \\
99 \\
104\end{array}$ & & \\
\hline W.H. & $\begin{array}{l}\text { S-L } \\
\text { T-D-L } \\
\text { T-D-S }\end{array}$ & $\begin{array}{l}65 \\
75 \\
85\end{array}$ & $\begin{array}{l}64 \\
82 \\
92\end{array}$ & $\begin{array}{l}61 \\
82 \\
95\end{array}$ & $\begin{array}{l}59 \\
92 \\
98\end{array}$ & $\begin{array}{r}57 \\
102 \\
106\end{array}$ & $\begin{array}{r}57 \\
-115 \\
110\end{array}$ & $\begin{array}{r}54 \\
115 \\
107\end{array}$ & $\begin{array}{r}44 \\
109 \\
104\end{array}$ & $\begin{array}{r}38 \\
104 \\
103\end{array}$ & $\begin{array}{r}40 \\
96 \\
102\end{array}$ & $\begin{array}{r}35 \\
96 \\
103\end{array}$ & $\begin{array}{r}38 \\
85 \\
100\end{array}$ & $\begin{array}{r}40 \\
88 \\
109\end{array}$ & $\begin{array}{r}37 \\
83 \\
109\end{array}$ & $\begin{array}{r}38 \\
84 \\
103\end{array}$ & $\begin{array}{r}44 \\
85 \\
101\end{array}$ & & & $\begin{array}{r}49 \\
86 \\
100\end{array}$ & & \\
\hline R.K. & $\begin{array}{l}\text { S-L } \\
\text { T-D-L } \\
\text { T-D-S }\end{array}$ & $\begin{array}{l}75 \\
91 \\
83\end{array}$ & $\begin{array}{l}82 \\
83 \\
87\end{array}$ & $\begin{array}{l}83 \\
90 \\
94\end{array}$ & $\begin{array}{r}83 \\
95 \\
104\end{array}$ & $\begin{array}{r}84 \\
101 \\
104\end{array}$ & $\begin{array}{r}83 \\
103 \\
104\end{array}$ & $\begin{array}{r}82 \\
102 \\
102\end{array}$ & $\begin{array}{r}71 \\
99 \\
101\end{array}$ & $\begin{array}{l}62 \\
92 \\
99\end{array}$ & $\begin{array}{l}46 \\
89 \\
98\end{array}$ & $\begin{array}{l}86 \\
96\end{array}$ & $\begin{array}{l}49 \\
84 \\
99\end{array}$ & $\begin{array}{r}65 \\
88 \\
102\end{array}$ & $\begin{array}{r}77 \\
91 \\
102\end{array}$ & $\begin{array}{r}79 \\
91 \\
103\end{array}$ & $\begin{array}{l}81 \dagger \\
92 \dagger \\
99 \dagger\end{array}$ & $\begin{array}{l}220 \\
210 \\
229\end{array}$ & $\begin{array}{l}183 \\
165 \\
190\end{array}$ & $\begin{array}{l}165 \\
155 \\
161\end{array}$ & $\begin{array}{l}131 \\
136 \\
140\end{array}$ & $\begin{array}{l}110 \\
124 \\
126\end{array}$ \\
\hline R.F. & $\begin{array}{l}\text { S-L } \\
\text { T-D-L } \\
\text { T-D-S }\end{array}$ & $\begin{array}{l}79 \\
80 \\
99\end{array}$ & $\begin{array}{r}80 \\
85 \\
102\end{array}$ & $\begin{array}{r}83 \\
92 \\
104\end{array}$ & $\begin{array}{r}82 \\
101 \\
109\end{array}$ & $\begin{array}{r}83 \\
112 \\
110\end{array}$ & $\begin{array}{r}83 \\
112 \\
112\end{array}$ & $\begin{array}{r}84 \\
108 \\
109\end{array}$ & $\begin{array}{r}77 \\
103 \\
109\end{array}$ & $\begin{array}{r}68 \\
98 \\
109\end{array}$ & $\begin{array}{r}58 \\
92 \\
108\end{array}$ & $\begin{array}{r}55 \\
92 \\
107\end{array}$ & $\begin{array}{r}52 \\
92 \\
108\end{array}$ & $\begin{array}{r}66 \\
92 \\
107\end{array}$ & $\begin{array}{r}73 \\
94 \\
107\end{array}$ & $\begin{array}{r}76 \\
100 \\
108\end{array}$ & $\begin{array}{r}79 \\
103 \\
106\end{array}$ & & & $\begin{array}{r}84 \\
106 \\
107\end{array}$ & & \\
\hline G.M. & $\begin{array}{l}\text { S-L } \\
\text { T-D-L }+K\end{array}$ & $\begin{array}{l}79 \\
86\end{array}$ & $\begin{array}{l}82 \\
88\end{array}$ & $\begin{array}{l}83 \\
92\end{array}$ & $\begin{array}{r}83 \\
102\end{array}$ & $\begin{array}{r}82 \\
107\end{array}$ & $\begin{array}{r}84 \\
110\end{array}$ & $\begin{array}{r}81 \\
109\end{array}$ & $\begin{array}{r}73 \\
106\end{array}$ & $\begin{array}{r}64 \\
102\end{array}$ & $\begin{array}{r}54 \\
101\end{array}$ & $\begin{array}{r}42 \\
101\end{array}$ & $\begin{array}{r}43 \\
105\end{array}$ & $\begin{array}{r}58 \\
115\end{array}$ & $\begin{array}{r}65 \\
108\end{array}$ & $\begin{array}{r}71 \\
103\end{array}$ & $\begin{array}{r}79 \\
104\end{array}$ & & & $\begin{array}{r}84 \\
110\end{array}$ & & \\
\hline B.E. & $\begin{array}{l}\text { S-L } \\
\text { T-D-L }+K\end{array}$ & $\begin{array}{l}79 \\
91\end{array}$ & $\begin{array}{l}81 \\
89\end{array}$ & $\begin{array}{l}81 \\
95\end{array}$ & $\begin{array}{r}81 \\
102\end{array}$ & $\begin{array}{r}81 \\
105\end{array}$ & $\begin{array}{r}80 \\
102\end{array}$ & $\begin{array}{r}77 \\
100\end{array}$ & $\begin{array}{l}71 \\
97\end{array}$ & $\begin{array}{l}63 \\
91\end{array}$ & $\begin{array}{l}51 \\
85\end{array}$ & $\begin{array}{l}40 \\
86\end{array}$ & $\begin{array}{l}42 \\
88\end{array}$ & $\begin{array}{l}52 \\
89\end{array}$ & $\begin{array}{l}57 \\
93\end{array}$ & $\begin{array}{l}65 \\
94\end{array}$ & $\begin{array}{l}69 \\
93\end{array}$ & & & $\begin{array}{l}75 \\
94\end{array}$ & & \\
\hline
\end{tabular}

* Details of experimental procedures are given in Methods. Saline, $300 \mathrm{ml}$, with or without $600 \mathrm{mg}$ of diazoxide was infused from -60 to 0 minutes. Leucine or saline was infused from 0 to 30 minutes. Tests: $(\mathrm{S}-\mathrm{L})=$ saline-leucine; $(\mathrm{T}-\mathrm{D}-\mathrm{L})=$ trichlormethiazide-diazoxide-leucine; $(\mathrm{T}-\mathrm{D}-\mathrm{S})=$ trichlormethiazide-diazoxide-saline; $(\mathrm{T}-\mathrm{D}-\mathrm{L}+\mathrm{K})=$ trichlormethiazide $+\mathrm{K}$-diazoxide $+\mathrm{K}$-leucine

$+50 \mathrm{ml}, 50 \%$ dextrose in water, iv.

insulin (immunoassay). In addition, the effects of these drugs upon plasma insulin and blood glucose levels of patients with insulin-producing islet cell tumors have been investigated. The results indicate that these benzothiadiazines increase blood glucose by mechanisms that do not involve alterations in levels of plasma insulin. However, in addition, they indicate clearly that 1 ) plasma levels of insulin decrease or do not rise when hyperglycemia is induced by benzothiadiazines, 2) the hyperinsulinemia and hypoglycemia that result from administration of leucine to chlorpropamide-pretreated subjects may be decreased by administration of benzothiadiazines, 3 ) the hyperinsulinemia of patients with insulin-secreting tumors is decreased by administration of benzothiadiazines, and 4) hyperinsulinemia induced by administration of glucose is decreased by the administration of benzothiadiazines. These results indicate that decreased insulin secretion as well as failure of appropriate increases in insulin release is involved in mechanisms by which trichlormethiazide and diazoxide induce hyperglycemia.

\section{Methods}

A) Studies in healthy subjects. Five healthy young men served as subjects for this study. The experimental design, employed in each subject, was as follows (Table
I) : 1) administration of chlorpropamide, $1.0 \mathrm{~g}$ on day 1 and $0.5 \mathrm{~g}$ daily thereafter (given at end of infusions on days 4 and 6$)$; 2) on day 4 , infusion of $300 \mathrm{ml}$ of saline over 60 minutes, followed by an infusion of leucine over 30 minutes $(0.2 \mathrm{~g}$ leucine per $\mathrm{kg}$ body $\mathrm{wt}, 20 \mathrm{mg}$ per $\mathrm{ml}$ dissolved in $0.45 \%$ saline) ; 3) administration of trichlormethiazide a) $2 \mathrm{mg}$ at 12 noon, 2 p.m., and 8 p.m. on day 4 and at 2 a.m., 8 a.m., 2 p.m., and 8 p.m. on day $5, b) 2 \mathrm{mg}$ at 2 a.m. and $8 \mathrm{mg}$ at 8 a.m. on day $6, c) 2$ $\mathrm{mg}$ at 2 a.m. and $8 \mathrm{mg}$ at 8 a.m. on day $7 ; 4$ ) on day 6 , infusion of $300 \mathrm{ml}$ of saline containing $600 \mathrm{mg}$ diazoxide (hyperstat) 4 over 60 minutes followed by an infusion of leucine (same amount as on day 4) over 30 minutes; and 5) on day 7, infusion of $300 \mathrm{ml}$ saline containing $600 \mathrm{mg}$ diazoxide over 60 minutes followed by an infusion of isotonic saline (10 $\mathrm{mg}$ per $\mathrm{kg}$ body wt) over 30 minutes.

In two subjects (G.M. and B.E.) the experimental plan for days 1 through 6 was repeated with the following modifications : $a$ ) oral administration of $160 \mathrm{mEq}$ potassium in four divided doses on days 4 and 5 , and 40 $\mathrm{mEq}$ at 8 a.m. on day $6, b$ ) inclusion of $30 \mathrm{mEq}$ of potassium in the infusions on day 6 , and $c$ ) omission of $8 \mathrm{mg}$ trichlormethiazide at $8 \mathrm{a} . \mathrm{m}$. on day 6 in subject B.E.

Blood for determination of blood glucose and plasma insulin was obtained every 15 minutes during the first hour ( -60 to 0 minutes in Tables II and III and Figure 1 ), every 10 minutes during the second hour ( 0 to 60 minutes), and every 15 minutes during the last $1 \frac{1}{2}$ hours (60 to 150 minutes) of the experiments. In one subject (R.K.) $25 \mathrm{~g}$ glucose was given intravenously at $120 \mathrm{~min}$ -

${ }^{4}$ Kindly supplied by Dr. J. Black, Schering Corp., Bloomfield, N. J. 
TABLE II

pretreated healthy subjects before and after administration of benzothiadiazine compounds

\begin{tabular}{|c|c|c|c|c|c|c|c|c|c|c|c|c|c|c|c|c|c|c|c|c|}
\hline \multirow[b]{2}{*}{-61} & \multicolumn{20}{|c|}{ Plasma insulin at time in minutes } \\
\hline & -60 & -45 & -30 & -15 & $\mathbf{0}$ & 10 & 20 & 30 & 40 & 50 & 60 & 75 & 90 & 105 & 120 & 130 & 140 & 150 & 165 & 180 \\
\hline \multicolumn{21}{|c|}{$\mu U / m l$} \\
\hline $\begin{array}{l}16 \\
20 \\
20\end{array}$ & $\begin{array}{l}20 \\
22 \\
28\end{array}$ & $\begin{array}{l}19 \\
10 \\
18\end{array}$ & $\begin{array}{r}20 \\
2 \\
14\end{array}$ & $\begin{array}{r}15 \\
8 \\
15\end{array}$ & $\begin{array}{r}16 \\
3 \\
22\end{array}$ & $\begin{array}{r}133 \\
30 \\
22\end{array}$ & $\begin{array}{r}122 \\
39 \\
22\end{array}$ & $\begin{array}{r}164 \\
42 \\
21\end{array}$ & $\begin{array}{r}164 \\
52 \\
19\end{array}$ & $\begin{array}{r}130 \\
70 \\
22\end{array}$ & $\begin{array}{l}95 \\
64 \\
27\end{array}$ & $\begin{array}{l}43 \\
63 \\
28\end{array}$ & $\begin{array}{l}24 \\
53 \\
26\end{array}$ & $\begin{array}{l}20 \\
44 \\
32\end{array}$ & $\begin{array}{l}15 \\
36 \\
27\end{array}$ & & & $\begin{array}{l}19 \\
29 \\
29\end{array}$ & & \\
\hline $\begin{array}{r}13 \\
11 \\
9\end{array}$ & $\begin{array}{r}12 \\
5 \\
14\end{array}$ & $\begin{array}{r}11 \\
3 \\
8\end{array}$ & $\begin{array}{r}12 \\
3 \\
7\end{array}$ & $\begin{array}{r}13 \\
4 \\
7\end{array}$ & $\begin{array}{r}10 \\
5 \\
13\end{array}$ & $\begin{array}{l}33 \\
11\end{array}$ & $\begin{array}{l}44 \\
26 \\
12\end{array}$ & $\begin{array}{r}70 \\
42 \\
8\end{array}$ & $\begin{array}{l}46 \\
28 \\
10\end{array}$ & $\begin{array}{l}37 \\
23 \\
11\end{array}$ & $\begin{array}{l}19 \\
18 \\
11\end{array}$ & $\begin{array}{l}11 \\
18 \\
14\end{array}$ & $\begin{array}{r}9 \\
11 \\
10\end{array}$ & $\begin{array}{r}6 \\
10 \\
13\end{array}$ & $\begin{array}{l}27 \\
12\end{array}$ & & & $\begin{array}{r}7 \\
13 \\
12\end{array}$ & & \\
\hline $\begin{array}{r}9 \\
15\end{array}$ & $\begin{array}{r}6 \\
15 \\
6\end{array}$ & $\begin{array}{r}9 \\
7 \\
13\end{array}$ & $\begin{array}{r}7 \\
2 \\
11\end{array}$ & $\begin{array}{l}7 \\
8 \\
5\end{array}$ & $\begin{array}{r}8 \\
11 \\
10\end{array}$ & $\begin{array}{r}37 \\
22 \\
7\end{array}$ & $\begin{array}{l}40 \\
42 \\
10\end{array}$ & $\begin{array}{l}72 \\
42 \\
10\end{array}$ & $\begin{array}{r}69 \\
44 \\
7\end{array}$ & $\begin{array}{r}58 \\
39 \\
9\end{array}$ & $\begin{array}{l}18 \\
38 \\
15\end{array}$ & $\begin{array}{l}32 \\
23 \\
18\end{array}$ & $\begin{array}{l}32 \\
16 \\
13\end{array}$ & $\begin{array}{l}16 \\
11 \\
15\end{array}$ & $\begin{array}{r}9 \\
10 \\
10\end{array}$ & & & $\begin{array}{r}8 \\
10 \\
16\end{array}$ & & \\
\hline $\begin{array}{l}5 \\
9 \\
9\end{array}$ & $\begin{array}{l}5 \\
8 \\
6\end{array}$ & $\begin{array}{l}5 \\
4 \\
8\end{array}$ & $\begin{array}{r}7 \\
5 \\
16\end{array}$ & $\begin{array}{l}7 \\
4 \\
6\end{array}$ & $\begin{array}{l}4 \\
7 \\
9\end{array}$ & $\begin{array}{r}26 \\
25 \\
3\end{array}$ & $\begin{array}{r}23 \\
24 \\
4\end{array}$ & $\begin{array}{r}29 \\
27 \\
4\end{array}$ & $\begin{array}{r}35 \\
25 \\
4\end{array}$ & $\begin{array}{r}15 \\
4\end{array}$ & $\begin{array}{r}9 \\
17 \\
5\end{array}$ & $\begin{array}{r}11 \\
7 \\
7\end{array}$ & $\begin{array}{r}12 \\
7 \\
6\end{array}$ & $\begin{array}{r}10 \\
6 \\
7\end{array}$ & $\begin{array}{l}5 t \\
6 t \\
8 \dagger\end{array}$ & $\begin{array}{l}65 \\
84 \\
25\end{array}$ & $\begin{array}{l}74 \\
70 \\
73\end{array}$ & $\begin{array}{l}83 \\
63 \\
44\end{array}$ & $\begin{array}{l}91 \\
43 \\
34\end{array}$ & $\begin{array}{l}32 \\
23 \\
\mathbf{3 4}\end{array}$ \\
\hline $\begin{array}{l}11 \\
16 \\
19\end{array}$ & $\begin{array}{l}10 \\
20 \\
17\end{array}$ & $\begin{array}{l}14 \\
13 \\
12\end{array}$ & $\begin{array}{r}6 \\
14 \\
13\end{array}$ & $\begin{array}{l}12 \\
14 \\
12\end{array}$ & $\begin{array}{l}10 \\
14 \\
14\end{array}$ & $\begin{array}{r}27 \\
35 \\
\cdot 14\end{array}$ & $\begin{array}{l}34 \\
40 \\
13\end{array}$ & $\begin{array}{l}46 \\
60 \\
14\end{array}$ & $\begin{array}{l}48 \\
51 \\
17\end{array}$ & $\begin{array}{l}40 \\
52 \\
15\end{array}$ & $\begin{array}{l}30 \\
50 \\
12\end{array}$ & $\begin{array}{l}24 \\
34 \\
17\end{array}$ & $\begin{array}{r}7 \\
28 \\
14\end{array}$ & $\begin{array}{r}5 \\
29 \\
14\end{array}$ & $\begin{array}{r}7 \\
19 \\
13\end{array}$ & & & $\begin{array}{l}12 \\
26 \\
14\end{array}$ & & \\
\hline $\begin{array}{l}12 \\
18\end{array}$ & $\begin{array}{l}11 \\
19\end{array}$ & $\begin{array}{l}11 \\
16\end{array}$ & $\begin{array}{r}13 \\
4\end{array}$ & $\begin{array}{r}12 \\
5\end{array}$ & $\begin{array}{l}12 \\
11\end{array}$ & $\begin{array}{l}66 \\
14\end{array}$ & $\begin{array}{l}80 \\
30\end{array}$ & $\begin{array}{r}174 \\
45\end{array}$ & $\begin{array}{r}161 \\
38\end{array}$ & $\begin{array}{l}85 \\
42\end{array}$ & $\begin{array}{l}58 \\
48\end{array}$ & $\begin{array}{l}28 \\
59\end{array}$ & $\begin{array}{l}17 \\
39\end{array}$ & $\begin{array}{l}14 \\
25\end{array}$ & $\begin{array}{l}12 \\
20\end{array}$ & & & $\begin{array}{l}19 \\
18\end{array}$ & & \\
\hline $\begin{array}{r}5 \\
20\end{array}$ & $\begin{array}{r}2 \\
20\end{array}$ & $\begin{array}{l}3 \\
9\end{array}$ & $\begin{array}{l}5 \\
5\end{array}$ & $\begin{array}{l}8 \\
8\end{array}$ & $\begin{array}{l}0 \\
6\end{array}$ & $\begin{array}{l}15 \\
47\end{array}$ & $\begin{array}{l}28 \\
36\end{array}$ & $\begin{array}{l}54 \\
52\end{array}$ & $\begin{array}{l}47 \\
24\end{array}$ & $\begin{array}{l}32 \\
22\end{array}$ & $\begin{array}{l}16 \\
16\end{array}$ & $\begin{array}{r}5 \\
11\end{array}$ & $\mathbf{1}$ & $\begin{array}{r}1 \\
15\end{array}$ & $\begin{array}{r}2 \\
10\end{array}$ & & & $\begin{array}{l}3 \\
9\end{array}$ & & \\
\hline
\end{tabular}

utes of the experiment and blood obtained 10, 20,30, 45, and 60 minutes thereafter.

Serum levels of sodium and potassium were determined at $-60,0$, and 150 minutes of all experiments on days 4,6 , and 7 .

In two subjects (G.M. and B.E.) intravenous insulin tolerance tests $(0.05 \mathrm{U}$ glucagon-free insulin per $\mathrm{kg}$ body wt) were performed during separate experiments 1) after infusion of $300 \mathrm{ml}$ of saline over 60 minutes, and 2) after oral administration of $8 \mathrm{mg}$ of trichlormethiazide in four divided doses per day for 2 days and of $8 \mathrm{mg}$ at 8 a.m. on the third day and an infusion of $300 \mathrm{ml}$ saline containing $600 \mathrm{mg}$ diazoxide over 60 minutes.
B) Studies in patients with insulin-secreting pancreatic islet cell adenoma. Six patients with insulin-secreting tumors were studied. All patients received a daily dietary carbohydrate intake of $300 \mathrm{~g}$ or more, which was kept constant within narrow limits. All patients received a constant midnight feeding. In addition, subject R.B. received a feeding either at 4 or at 3 a.m. and $5: 30$ a.m. as indicated in Table IV. Daily determinations of blood glucose and plasma insulin were performed for 12 to 40 days before removal of the tumor. Control infusions of saline ( $300 \mathrm{ml}$ over 60 minutes) as well as intravenous glucose tolerance tests (rapid injection of $25 \mathrm{~g}$ of glucose in a $50 \%$ solution) were carried out before adminis-

TABLE III

Levels of serum sodium and potassium before and after administration of benzothiadiazıne drugs to healthy subjects*

\begin{tabular}{|c|c|c|c|c|c|c|c|c|c|c|c|c|c|c|c|c|c|c|}
\hline \multirow[b]{2}{*}{ Subject } & \multicolumn{9}{|c|}{ Serum sodium at time in minutes } & \multicolumn{9}{|c|}{ Serum potassium at time in minutes } \\
\hline & $-60 t$ & $0 \dagger$ & $150 \dagger$ & $-60 \ddagger$ & of & $150 \ddagger$ & -608 & $0 \S$ & 1508 & $-60 \dagger$ & of & $150 \dagger$ & $-60 \ddagger$ & $0 \ddagger$ & $150 t$ & $-60 \S$ & $0 \$$ & 1508 \\
\hline & \multicolumn{9}{|c|}{$m E q / L$} & \multicolumn{9}{|c|}{$m E q / L$} \\
\hline G.M. & 141 & 141 & 141 & 141 & 141 & 136 & 136 & 135 & 132 & 4.2 & 4.2 & 4.0 & 3.6 & & & 3.3 & 3.3 & 3.3 \\
\hline B.E. & 139 & 139 & 136 & 136 & 133 & 133 & 136 & 136 & 136 & 4.5 & 4.5 & 4.3 & 4.0 & 3.9 & 4.0 & 3.6 & 3.8 & 3.5 \\
\hline W.H. & 138 & 138 & 141 & 135 & 135 & 135 & 138 & 135 & 138 & 4.5 & 4.6 & 4.3 & 3.9 & 3.9 & 3.8 & 3.8 & 3.6 & 3.7 \\
\hline R.K. & 142 & 144 & 144 & 141 & 138 & 132 & 141 & 135 & 135 & 4.6 & 3.9 & 3.9 & 4.7 & 3.8 & 3.6 & 4.1 & 3.6 & 3.7 \\
\hline R.F. & 141 & 140 & 140 & 140 & 140 & 136 & 140 & 140 & 140 & 4.6 & 4.9 & 4.9 & 4.0 & 4.0 & 3.6 & 3.3 & 3.4 & 3.7 \\
\hline Mean & 140.2 & 140.4 & 140.4 & 138.6 & 137.4 & 134.4 & 138.2 & 136.2 & 136.2 & 4.48 & 4.42 & 4.28 & 4.04 & 3.90 & 3.75 & 3.62 & 3.54 & 3.58 \\
\hline G.M. & $138 \dagger$ & $138 \dagger$ & $138 \dagger$ & $138 \|$ & $138 \|$ & $138 \|$ & & & & $4.8 \dagger$ & $4.8 \dagger$ & $4.0 \dagger$ & $4.0 \|$ & $4.9 \|$ & $3.7 \|$ & & & \\
\hline B.E. & $138 t$ & $138 t$ & $138 t$ & $138 \|$ & $135 \|$ & $132 \|$ & & & & $5.0 \dagger$ & $5.0 \dagger$ & $4.6 t$ & $4.9 \|$ & $5.9 \|$ & 4.4\| & & & \\
\hline
\end{tabular}

* Details of experimental procedures are given in Methods. Saline, $300 \mathrm{ml}$, with or without $600 \mathrm{mg}$ of diazoxide was infused from -60 to 0 minutes. Leucine or saline was infused from 0 to 30 minutes.

t Saline-leucine test.

Trichlormethiazide-diazoxide-leucine test.

Trichlormethiazide-diazoxide-saline test.

Trichlormethiazide $+\mathrm{K}$-diazoxide $+\mathrm{K}$-leucine test. 


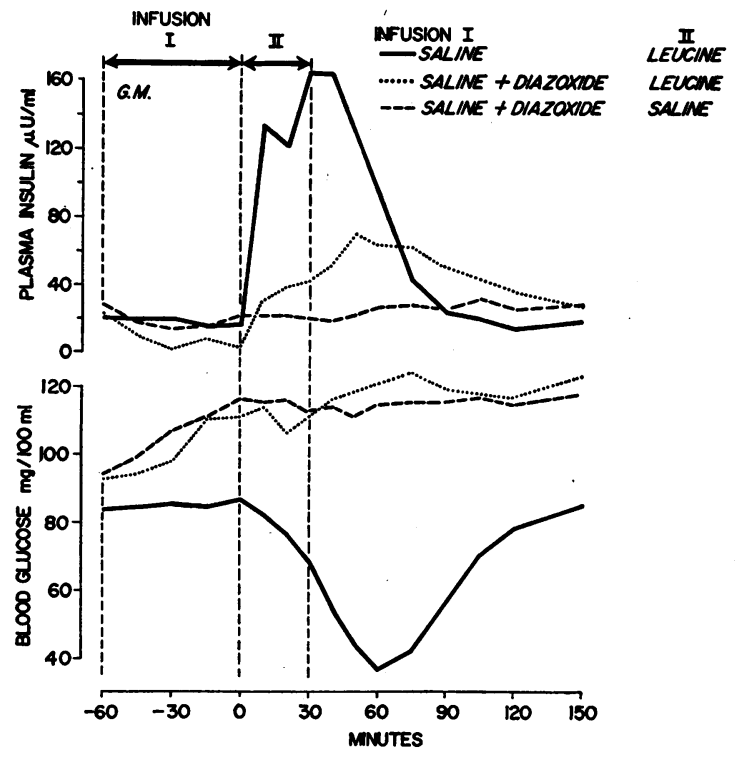

Fig. 1. EFfects of trichlormethiazide and diazoXIDE UPON PLASMA INSULIN AND BLOOD GLUCOSE AND ON RESPONSE TO LEUCINE IN A CHLORPROPAMIDE-PRETREATED HEALTHY SUBJECT.

tration of benzothiadiazines. Trichlormethiazide in a dose of 1 to $8 \mathrm{mg}$ per day was administered orally as indicated in Figure 2 and Table IV: Intravenous infusions of diazoxide ( 450 to $600 \mathrm{mg}$ in $300 \mathrm{ml}$ of saline) were given over 60 minutes. Twenty-five $g$ of glucose was given intravenously 90 to 150 minutes after the beginning of the diazoxide infusion. Blood for determina- tion of blood glucose and plasma insulin was obtained at frequent intervals starting 30 minutes before the beginning of the diazoxide infusion and ending 60 minutes after administration of glucose. Diazoxide was administered orally to five patients in a dose of 180 to $510 \mathrm{mg}$ per day for 3 to 28 days as indicated in Table IV. (The intravenous preparation "hyperstat" was given to patients S.L., L.W., and A.W., whereas H.R. and R.B. received capsules containing crystalline diazoxide.)

Blood levels of glucose were determined with the Technicon Auto-Analyzer and frequently verified by the Somogyi-Nelson technique (17). Plasma levels of insulin were determined by the immunoassay of Yalow and Berson (18) as previously described in detail from this laboratory $(15,19)$.

\section{Results}

\section{Healthy subjects}

Levels of blood glucose and plasma insulin obtained during the seven series of experiments in the five healthy subjects are shown in Table II; Figure 1 illustrates the principal findings.

Blood glucose. Before administration of benzothiadiazine compounds, infusion of leucine produced large decreases in blood glucose in all the chlorpropamide-pretreated subjects $(p<0.001)$. Administration of trichlormethiazide for 2 days resulted in an increase in fasting blood glucose levels in six of the seven experiments (mean increase of $8 \mathrm{mg}$ per $100 \mathrm{ml} ; \mathrm{p}<0.01$ ). Infusion of di-

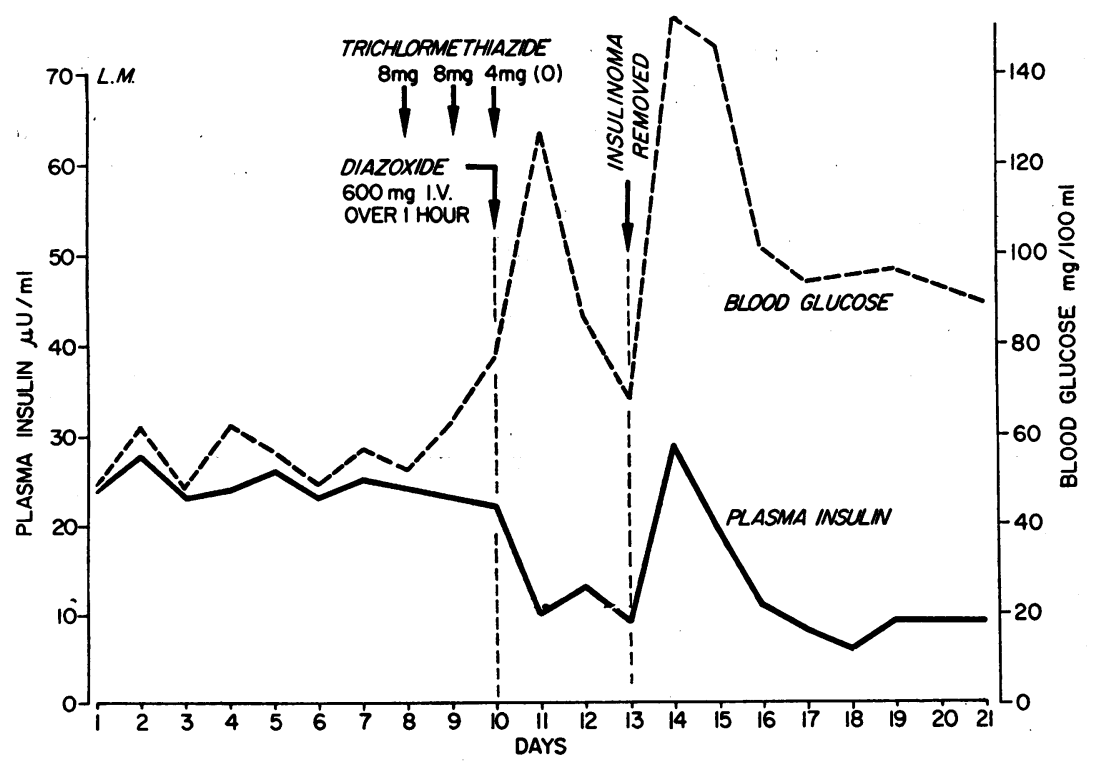

Fig. 2. EFFECTS OF TRICHLORMETHIAZIDE AND DIAZOXIDE ON DAILY LEVELS OF PLASMA INSULIN AND BLOOD GLUCOSE IN A PATIENT WITH AN INSULIN-SECRETING PANCREATIC ISLET CELL TUMOR. 
TABLE IV

Effects of administration of benzothiadiazine drugs on mean levels of blood glucose and plasma insulin in five patients with insulin-secreting islet cell tumors

\begin{tabular}{|c|c|c|c|c|c|c|c|c|c|}
\hline \multirow[b]{2}{*}{ Patient } & \multirow[b]{2}{*}{$\begin{array}{c}\text { Benzothiadiazine } \\
\text { administration }\end{array}$} & \multicolumn{4}{|c|}{$\begin{array}{l}\text { 7:30-8 a.m. } \\
\text { (Last feeding at midnight unless } \\
\text { stated otherwise) }\end{array}$} & \multicolumn{4}{|c|}{ Afternoon* } \\
\hline & & $\begin{array}{l}\text { Blood } \\
\text { glucose }\end{array}$ & $\mathbf{p}$ & Insulin & p & $\begin{array}{c}\text { Blood } \\
\text { glucose }\end{array}$ & p & Insulin & $\mathbf{p}$ \\
\hline \multirow[t]{2}{*}{ S.L. } & Before (14 days) & $\begin{array}{l}m g / 100 m l \\
\quad 95\end{array}$ & \multirow{2}{*}{$<0.005$} & $\begin{array}{c}\mu U / m l \\
43\end{array}$ & \multirow{2}{*}{$<0.005$} & $\begin{array}{c}m g / 100 m l \\
31\end{array}$ & & $\begin{array}{c}\mu U / m l \\
100\end{array}$ & \multirow{2}{*}{$<0.001$} \\
\hline & During $\dagger$ and 2 days after & 164 & & 22 & & 117 & $<0.001$ & 32 & \\
\hline L.W. & $\begin{array}{l}\text { Before ( } 11 \text { days) } \\
\text { During } \ddagger \text { and } 2 \text { days after }\end{array}$ & $\begin{array}{l}59 \\
72\end{array}$ & & $\begin{array}{l}25 \\
17\end{array}$ & & & & & \\
\hline A.W. & Before (11 days) & 66 & \multirow{2}{*}{$<0.001$} & 20 & \multirow{2}{*}{$<0.005$} & 68 & \multirow{2}{*}{$<0.005$} & 106 & \multirow{2}{*}{$<0.005$} \\
\hline & During $\S$ and 2 days after & 90 & & 10 & & 89 & & 38 & \\
\hline \multirow[t]{2}{*}{ H.R. } & Before (10 days) & 57 & \multirow{2}{*}{$<0.001$} & 64 & \multirow{2}{*}{$<0.005$} & & & & \multirow{7}{*}{$<0.05$} \\
\hline & During $\|$ - & 68 & & 46 & & & & & \\
\hline \multirow[t]{5}{*}{ R.B. } & $\begin{array}{l}\text { Before ( } 6 \text { days) } \\
\text { with } 4 \text { a.m. feeding }\end{array}$ & 47 & & 96 & & \multirow[t]{3}{*}{64} & \multirow{3}{*}{$<0.05$} & 128 & \\
\hline & $\begin{array}{l}\text { Before (6 days) } \\
\text { with } 3 \text { a.m. and } \\
5: 30 \text { a.m. feedings }\end{array}$ & 69 & & 97 & & & & & \\
\hline & & & $\begin{array}{l}\text { vs. "4 a.m. } \\
\text { before" }\end{array}$ & & $\begin{array}{l}\text { vs. "4 a.m. } \\
\text { before" }\end{array}$ & & & & \\
\hline & with 4 a.m. feeding & 95 & $<0.005$ & 72 & $<0.005$ & \multirow{2}{*}{85} & \multirow{2}{*}{\multicolumn{2}{|c|}{94}} & \\
\hline & During** & 120 & $<0.001$ & 58 & $<0.001$ & & & & \\
\hline
\end{tabular}

* 2 hour postprandial-S.L.; 4 hour postprandial-A.W.; 3 hour postprandial-R.B.

$\dagger 1,820 \mathrm{mg}$ diazoxide and $3 \mathrm{mg}$ trichlormethiazide over 4 days (includes day diazoxide given intravenously).

$\ddagger 2,220 \mathrm{mg}$ diazoxide and $11 \mathrm{mg}$ trichlormethiazide over 5 days (includes day diazoxide given intravenously).

$\$ 4,775 \mathrm{mg}$ diazoxide and $17 \mathrm{mg}$ trichlormethiazide over 12 days (includes day diazoxide given intravenously).

|| 3,200 mg diazoxide and $37 \mathrm{mg}$ trichlormethiazide over 9 days (includes day diazoxide given intravenously).

T 2,400 mg diazoxide and $28 \mathrm{mg}$ trichlormethiazide over 7 days (includes day diazoxide given intravenously).

** 5,700 mg diazoxide and $53 \mathrm{mg}$ trichlormethiazide over 21 days.

azoxide after administration of trichlormethiazide produced definite increases in blood glucose levels in all subjects tested (maximal increases 13 to 33 $\mathrm{mg}$, mean $22 \mathrm{mg}$ per $100 \mathrm{ml} ; \mathrm{p}<0.001$ ). When this infusion was followed by the infusion of leucine, the hypoglycemic effect of leucine was diminished in four of five subjects.

Almost identical results were obtained in subjects G.M. and B.E. when these experiments were repeated with a total of $390 \mathrm{mEq}$ of potassium administered over 2 days with concomitant administration of the benzothiadiazine drugs.

During the intravenous insulin tolerance tests performed in subjects G.M. and B.E., maximal decreases in blood glucose were of the same order of magnitude when performed before and with administration of trichlormethiazide and diazoxide (from 80 to $54 \mathrm{mg}$ per $100 \mathrm{ml}$ and from 80 to 40 $\mathrm{mg}$ per $100 \mathrm{ml}$ before administration of benzothiadiazines, and from 147 to $112 \mathrm{mg}$ per $100 \mathrm{ml}$ and 112 to $64 \mathrm{mg}$ per $100 \mathrm{ml}$, respectively, after administration of benzothiadiazines).

Plasma levels of insulin. In chlorpropamidepretreated subjects, infusion of leucine produced large increases in plasma levels of insulin in all subjects $(p<0.001)$. After administration of trichlormethiazide, insulin levels did not increase during any of the 12 infusions of diazoxide even though blood glucose levels rose on each occasion. On the contrary, there were either definite decreases or a trend to decreases in plasma levels of insulin during the infusions of diazoxide on day 6 of the experiments (trichlormethiazide-diazoxideleucine series, Table II ; $p<0.005)$. Similar elevations of blood glucose levels (maximal increases 10 to $29 \mathrm{mg}$, mean $20 \mathrm{mg}$ per $100 \mathrm{ml}$ ) after intra- 
TABLE $Y$

Effect of intravenous administration of diazoxide upon levels of blood glucose

\begin{tabular}{|c|c|c|c|c|c|c|c|c|c|c|c|c|c|c|}
\hline \multirow[b]{2}{*}{ Patient } & \multirow{2}{*}{$\begin{array}{c}\text { Infusion of saline or } \\
\text { diazoxide } 0 \text { to } 60 \\
\text { minutes }\end{array}$} & \multicolumn{13}{|c|}{ Blood glucose at time in minutes } \\
\hline & & -30 & -15 & $\mathbf{0}$ & 15 & 30 & 45 & 60 & 75 & 90 & 105 & 120 & 150 & 180 \\
\hline & & \multicolumn{13}{|c|}{$m g / 100 \mathrm{ml}$} \\
\hline R.B. & $\begin{array}{c}\text { Saline } \\
\text { Diazoxide, } 600 \mathrm{mg}^{*}\end{array}$ & $\begin{array}{l}77 \\
60\end{array}$ & $\begin{array}{l}85 \\
64\end{array}$ & $\begin{array}{l}83 \\
69\end{array}$ & $\begin{array}{l}76 \\
69\end{array}$ & $\begin{array}{l}81 \\
71\end{array}$ & $\begin{array}{l}75 \\
71\end{array}$ & $\begin{array}{l}76 \\
72\end{array}$ & 85 & $\begin{array}{l}66 \\
92\end{array}$ & 100 & $\begin{array}{r}57 \\
106\end{array}$ & $\begin{array}{r}40 \\
117\end{array}$ & \\
\hline H.R. & $\begin{array}{c}\text { Saline } \\
\text { Diazoxide, } 600 \mathrm{mg}^{*}\end{array}$ & $\begin{array}{l}58 \\
56\end{array}$ & $\begin{array}{l}58 \\
65\end{array}$ & $\begin{array}{l}51 \\
65\end{array}$ & 53 & $\begin{array}{l}53 \\
67\end{array}$ & $\begin{array}{l}50 \\
72\end{array}$ & 45 & 80 & $\begin{array}{l}42 \\
89\end{array}$ & 97 & $\begin{array}{r}38 \\
107\end{array}$ & $\begin{array}{r}35 \\
101\end{array}$ & 35 \\
\hline S.L. & $\begin{array}{c}\text { Saline } \\
\text { Diazoxide, } 500 \mathrm{mg} \dagger\end{array}$ & $\begin{array}{l}122 \\
115\end{array}$ & 112 & $\begin{array}{l}104 \\
107\end{array}$ & 102 & $\begin{array}{r}95 \\
110\end{array}$ & 127 & $\begin{array}{r}71 \\
154\end{array}$ & 177 & $\begin{array}{r}42 \\
204\end{array}$ & 232 & $\begin{array}{r}34 \\
256\end{array}$ & 36 & 40 \\
\hline
\end{tabular}

* Trichlormethiazide, $4 \mathrm{mg}$ per day, had been given orally on preceding 2 days and again 1 hour before infusion.

$\dagger$ Diazoxide, $1,320 \mathrm{mg}$, had been given orally during preceding 3 days.

venous administration of $5 \mathrm{~g}$ of glucose or 0.006 to $0.05 \mathrm{mg}$ of glucagon to healthy subjects (11 tests) were accompanied by a mean increase in plasma levels of insulin of $10 \mu \mathrm{U}$ per $\mathrm{ml}$. These changes in plasma insulin are significantly different from those obtained during the infusions of diazoxide $(\mathrm{p}<0.001)$.

Infusion of leucine after administration of trichlormethiazide and diazoxide resulted in lesser increases in plasma levels of insulin than before administration of these agents in three of the five subjects (G.M., B.E., W.H.). In subject R.K. there was no significant decrease in plasma levels of insulin when leucine was administered after benzothiadiazines. However, when glucose was administered intravenously to this subject 2 hours after the end of the leucine infusion, the sum of the increments in plasma levels of insulin over 60minutes was less after 2 and 3 days of administration of benzothiadiazines ( 253 and $170 \mu \mathrm{U}$ per ml,

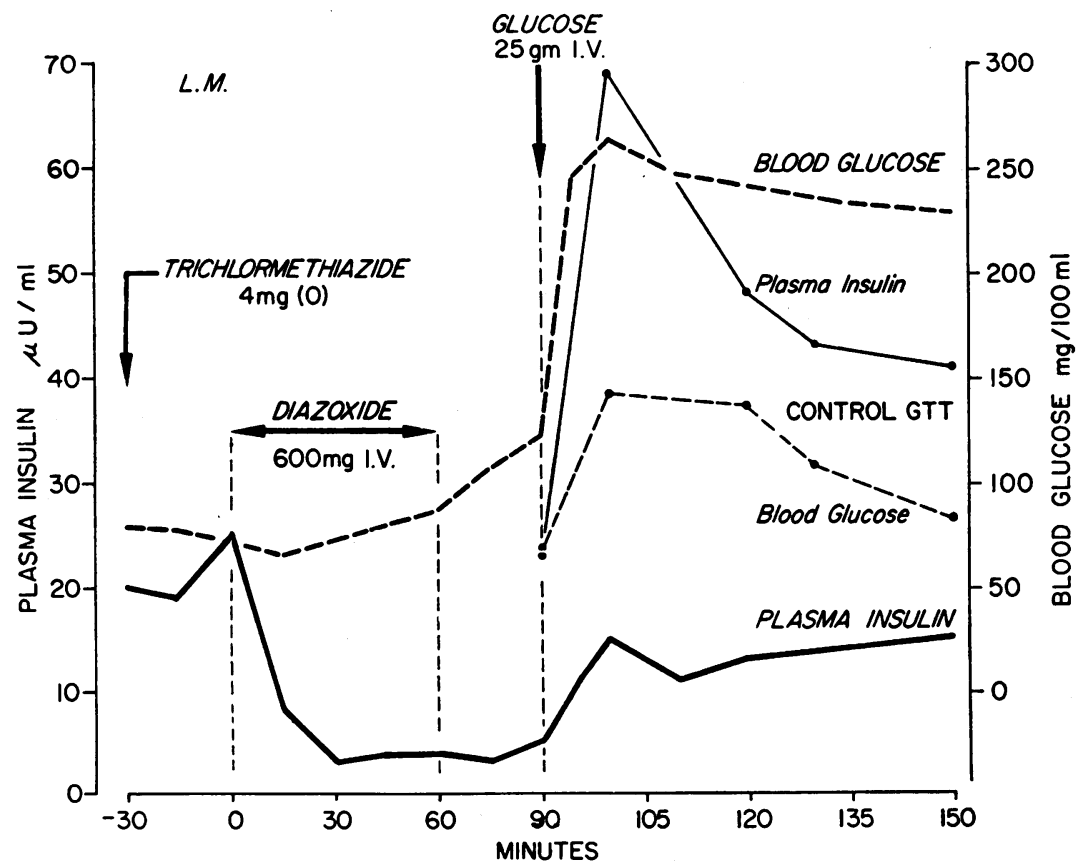

Fig. 3. EFFECTS OF TRICHLORMETHIAZIDE AND DIAZOXIDE UPON PLASMA INSULIN AND BLOOD GLUCOSE IN A PATIENT WITH AN INSULIN-SECRETING PANCREATIC ISLET CELL TUMOR. Trichlormethiazide, $8 \mathrm{mg}$ per day, had been given orally $(\mathrm{O})$ for 2 preceding days. GTT $=$ glucose tolerance test. 
TABLE V

and plasma insulin in three patients with insulin-secreting islet cell tumors

\begin{tabular}{|c|c|c|c|c|c|c|c|c|c|c|c|c|}
\hline \multicolumn{13}{|c|}{ Plasma insulin at time in minutes } \\
\hline-30 & -15 & $\mathbf{0}$ & 15 & 30 & 45 & 60 & 75 & 90 & 105 & 120 & 150 & 180 \\
\hline & & & & & & $U / m l$ & & & & & & \\
\hline $\begin{array}{l}117 \\
132\end{array}$ & $\begin{array}{r}99 \\
124\end{array}$ & $\begin{array}{l}113 \\
112\end{array}$ & $\begin{array}{r}99 \\
106\end{array}$ & $\begin{array}{l}106 \\
102\end{array}$ & $\begin{array}{r}109 \\
91\end{array}$ & $\begin{array}{r}123 \\
91\end{array}$ & 93 & $\begin{array}{r}130 \\
90\end{array}$ & 87 & $\begin{array}{r}134 \\
76\end{array}$ & $\begin{array}{r}140 \\
92\end{array}$ & \\
\hline $\begin{array}{l}61 \\
57\end{array}$ & $\begin{array}{l}60 \\
63\end{array}$ & $\begin{array}{l}45 \\
62\end{array}$ & 57 & $\begin{array}{l}56 \\
28\end{array}$ & $\begin{array}{l}54 \\
26\end{array}$ & 53 & 37 & $\begin{array}{l}52 \\
41\end{array}$ & 37 & $\begin{array}{l}48 \\
32\end{array}$ & $\begin{array}{l}50 \\
32\end{array}$ & 50 \\
\hline $\begin{array}{l}44 \\
20\end{array}$ & 23 & $\begin{array}{l}49 \\
19\end{array}$ & 20 & $\begin{array}{l}58 \\
16\end{array}$ & 17 & $\begin{array}{l}68 \\
14\end{array}$ & 17 & $\begin{array}{l}65 \\
14\end{array}$ & 11 & $\begin{array}{l}58 \\
13\end{array}$ & 50 & 50 \\
\hline
\end{tabular}

respectively) than before administration of benzothiadiazines ( $320 \mu \mathrm{U}$ per $\mathrm{ml})$. In subject R.F. leucine induced increases in plasma insulin that were greater after administration of benzothiadiazines. However, as in the other subjects, the rise in blood glucose levels ( $27 \mathrm{mg}$ per $100 \mathrm{ml}$ ) produced by infusion of diazoxide did not evoke an increase in plasma insulin.

When the experiments were repeated with potassium administered concomitantly with the benzothiadiazine drugs, almost identical decreases in plasma levels of insulin were obtained in subject G.M. (Table II).

In subject B.E. the infusion of leucine after administration of benzothiadiazines and potassium did not cause lesser increases of plasma insulin than before benzothiadiazines. This subject did not receive the $8 \mathrm{mg}$ of trichlormethiazide just before the diazoxide infusion, as on the previous occasion. However, as in the previous experiment, there was a decrease in plasma levels of insulin during the infusion of diazoxide, whereas blood levels of glucose were rising.

Serum levels of sodium and potassium. Serum levels of sodium and potassium obtained during the experiments reported in Table II are given in Table III.

\section{Patients with insulin-secreting pancreatic islet cell tumors}

Infusion of diazoxide. In patient L.M., daily fasting levels of insulin ${ }^{5}$ varied between 23 and $28 \mu \mathrm{U}$ per $\mathrm{ml}$ for 7 days before administration of

$\mathbf{5}$ In this laboratory mean fasting level of plasma insulin in 105 nondiabetic subjects is $11 \mu \mathrm{U}$ per $\mathrm{ml}$ with a standard deviation of $6.8 \mu \mathrm{U}$ per $\mathrm{ml}$. benzothiadiazines (Figure 2). Fasting blood glucose levels varied between 42 and $62 \mathrm{mg}$ per 100 $\mathrm{ml}$. After administration of trichlormethiazide for 2 days, intravenous infusion of diazoxide produced a decrease in plasma insulin from 25 to 3 to $5 \mu \mathrm{U}$ per $\mathrm{ml}$ (Figure 3 ), accompanied by an increase in blood glucose from 78 to $120 \mathrm{mg}$ per $100 \mathrm{ml} 90$ minutes after the beginning of the infusion. The control infusion of saline before administration of trichlormethiazide did not cause a similar decrease in plasma insulin or an increase in blood glucose. Intravenous administration of $25 \mathrm{~g}$ of glucose 90 minutes after the beginning of the diazoxide infusion caused a maximal increase in plasma insulin of only $10 \mu \mathrm{U}$ per ml, accompanied by a large increase in blood glucose (Figure 3). Intravenous administration of glucose before administration of benzothiadiazines had evoked a maximal increase in plasma insulin of $46 \mu \mathrm{U}$ per $\mathrm{ml}$ accompanied by a smaller increase in blood glucose (Figure 3 ).

On the 3 days after administration of diazoxide to this patient, plasma levels of insulin were 10 , 13 , and $9 \mu \mathrm{U}$ per $\mathrm{ml}$, whereas fasting blood glucose levels were 127,86 , and $68 \mathrm{mg}$ per $100 \mathrm{ml}$ (Figure 2). Several days after surgical removal of the functioning islet cell tumor, plasma levels of insulin were below $10 \mu \mathrm{U}$ per ml, whereas fasting blood glucose levels were in the normal range.

The effects of the infusion of saline or diazoxide upon blood glucose and plasma insulin in patients R.B., H.R., and S.L. are given in Table V. In each case blood glucose fell significantly during and after infusion of saline but rose 42 to $154 \mathrm{mg}$ per $100 \mathrm{ml}$ during a period of 120 to 150 minutes after the beginning of the diazoxide infusion. Plasma insulin remained constant or rose during 
the saline control test. After infusion of diazoxide, plasma insulin fell significantly in all three patients. Two other patients (L.W. and A.W.) who, like patient S.L., had also received diazoxide orally for several days before the infusion of diazoxide exhibited qualitatively similar effects. However, since plasma levels of insulin were at or below 10 $\mu \mathrm{U}$ per $\mathrm{ml}$ immediately before the infusion of diazoxide, decreases of plasma insulin were small.

Twenty-four hours after the infusion of diazoxide, patient R.B. was fasted until 12 noon, his last feeding having been at 4 a.m. Blood glucose levels at 8,10 , and 11 a.m. and 12 noon were 101, 91, 82 , and $90 \mathrm{mg}$ per $100 \mathrm{ml}$, respectively. Plasma levels of insulin at the same time intervals were $82,84,79$, and $66 \mu \mathrm{U}$ per $\mathrm{ml}$. During a similar period of fasting (saline control test, Table V) blood glucose fell from 77 to $40 \mathrm{mg}$ per $100 \mathrm{ml}$ and plasma levels of insulin were considerably higher (99 to $140 \mu \mathrm{U}$ per $\mathrm{ml}$ ).

Patient H.R. was fasted from midnight until noon 2 days after the infusion of diazoxide. On the day preceding this fast, she received $300 \mathrm{mg}$ of diazoxide and $3 \mathrm{mg}$ of trichlormethiazide orally in three divided doses. Blood glucose levels at 7 and $10: 30$ a.m. and 12 noon were 81,77 , and 87 $\mathrm{mg}$ per $100 \mathrm{ml}$, respectively. Plasma levels of insulin at the same time intervals were 49,33 , and $42 \mu \mathrm{U}$ per $\mathrm{ml}$. During a similar fast (saline control test, Table V) blood glucose fell from 58 to $35 \mathrm{mg}$ per $100 \mathrm{ml}$, whereas plasma levels of insulin ranged between 45 and $61 \mu \mathrm{U}$ per $\mathrm{ml}$.

Increases in levels of blood glucose and plasma insulin produced by intravenous administration of glucose 120 to 150 minutes after the beginning of infusion of diazoxide are given in Table VI. Increases in insulin levels were greatly depressed after administration of the benzothiadiazine drugs (maximal increases $11,11,12$, and $18 \mu \mathrm{U}$ per $\mathrm{ml}$, respectively) as compared to control experiments performed before the administration of benzothiadiazines (maximal increases 47, 60, 68, and 69 $\mu \mathrm{U}$ per ml, respectively).

Administration of trichlormethiazide and diazoxide for 4 to 28 days. Administration of benzothiadiazines for more prolonged periods of time to five patients with insulin-secreting tumors produced large increases in blood glucose and significant decreases in plasma insulin in the fasting state as well as postprandially (Table IV). In subject S.L. an increase in the fasting blood glucose level into the hyperglycemic range (mean $164 \mathrm{mg}$ per $100 \mathrm{ml}$ ) was associated with a decrease in plasma insulin from a mean fasting level of $43 \mu \mathrm{U}$ per $\mathrm{ml}$ to a mean level of $22 \mu \mathrm{U}$ per ml. In subjects L.W., A.W., and H.R., increases in blood glucose levels from the mildly hypoglycemic to the normal range were accompanied by significant decreases in fasting plasma levels of insulin. The decreases in plasma levels of insulin that occurred with administration of benzothiadiazines were even more striking in samples obtained postprandially (Table IV). In patients S.L. and L.W. the decreases in plasma levels of insulin persisted for 4 days after discontinuation of benzothiadiazines up to the day of surgical removal of the insulinoma.

In subject R.B., the severity of fasting hypo-

TABLE VI

Increases in levels of blood glucose and plasma insulin after rapid intravenous administration of $25 \mathrm{~g}$ of glucose in four patients with insulin-secreting islet cell tumors*

\begin{tabular}{|c|c|c|c|c|c|c|c|c|c|c|c|c|c|c|c|c|c|}
\hline \multirow[b]{2}{*}{ Subject } & \multirow[b]{2}{*}{ Infusion } & \multicolumn{8}{|c|}{ Increase in blood glucose at time in minutes } & \multicolumn{8}{|c|}{ Increase in plasma insulin at time in minutes } \\
\hline & & 10 & 15 & 20 & 30 & 40 & 45 & 50 & 60 & $\overline{10}$ & 15 & 20 & 30 & 40 & 45 & 50 & 60 \\
\hline S.L. & $\begin{array}{l}\text { Control } \\
\text { Diazoxide }\end{array}$ & $\begin{array}{l}103 \\
170\end{array}$ & & $\begin{array}{r}53 \\
153\end{array}$ & $\begin{array}{r}m g / 1 \\
23 \\
148\end{array}$ & $\begin{array}{c}0 \mathrm{ml} \\
6\end{array}$ & 133 & 3 & $\begin{array}{r}2 \\
118\end{array}$ & $\begin{array}{r}60 \\
0\end{array}$ & & $\begin{array}{r}23 \\
1\end{array}$ & $\begin{array}{r}-2 \\
5\end{array}$ & $\begin{array}{l}\mu U / m l \\
-18\end{array}$ & 8 & -29 & $\begin{array}{r}-35 \\
11\end{array}$ \\
\hline L.W. & $\begin{array}{l}\text { Control } \\
\text { Diazoxide }\end{array}$ & $\begin{array}{l}182 \\
157\end{array}$ & 146 & 135 & $\begin{array}{r}96 \\
121\end{array}$ & & $\begin{array}{r}61 \\
109\end{array}$ & & $\begin{array}{l}31 \\
91\end{array}$ & $\begin{array}{l}59 \\
12\end{array}$ & 69 & 4 & $\begin{array}{r}28 \\
0\end{array}$ & & $\begin{array}{r}13 \\
-2\end{array}$ & & $\begin{array}{l}-1 \\
-4\end{array}$ \\
\hline A.W. & $\begin{array}{l}\text { Control } \\
\text { Diazoxide }\end{array}$ & $\begin{array}{r}98 \\
101\end{array}$ & & $\begin{array}{l}94 \\
87\end{array}$ & $\begin{array}{l}79 \\
77\end{array}$ & & $\begin{array}{l}63 \\
69\end{array}$ & & $\begin{array}{l}49 \\
63\end{array}$ & $\begin{array}{l}28 \\
18\end{array}$ & & $\begin{array}{r}68 \\
2\end{array}$ & $\begin{array}{r}16 \\
4\end{array}$ & & $\begin{array}{l}9 \\
3\end{array}$ & & $\begin{array}{r}12 \\
3\end{array}$ \\
\hline H.R. & $\begin{array}{l}\text { Control } \\
\text { Diazoxide }\end{array}$ & $\begin{array}{l}146 \\
149\end{array}$ & & $\begin{array}{l}110 \\
130\end{array}$ & $\begin{array}{r}92 \\
126\end{array}$ & & $\begin{array}{l}63 \\
97\end{array}$ & & $\begin{array}{l}50 \\
92\end{array}$ & $\begin{array}{l}47 \\
11\end{array}$ & & $\begin{array}{l}20 \\
10\end{array}$ & $\begin{array}{l}1 \\
7\end{array}$ & & $\begin{array}{r}-4 \\
5\end{array}$ & & -1 \\
\hline
\end{tabular}

* Glucose was given 120 to 150 minutes after the beginning of diazoxide or control infusion. 
glycemia after an 8-hour fast necessitated more frequent feedings. With a 4 a.m. feeding (a glass of milk and a jelly sandwich) the mean level of blood glucose at 8 a.m. was $47 \mathrm{mg}$ per $100 \mathrm{ml}$ and mean plasma insulin was $96 \mu \mathrm{U}$ per $\mathrm{ml}$. When feedings were given at 3 and 5:30 a.m., mean levels were $69 \mathrm{mg}$ per $100 \mathrm{ml}$ and $97 \mu \mathrm{U}$ per $\mathrm{ml}$, respectively. After administration of benzothiadiazines for 7 days, mean levels were $95 \mathrm{mg}$ per 100 $\mathrm{ml}$ and $72 \mu \mathrm{U}$ per $\mathrm{ml}$ while a 4 a.m. feeding was given. Because of the correction of hypoglycemia, the 4 a.m. feeding was discontinued. During the next 21 days of benzothiadiazine administration, mean fasting blood glucose was $120 \mathrm{mg}$ per 100 $\mathrm{ml}$, and mean fasting plasma insulin was $58 \mu \mathrm{U}$ per $\mathrm{ml}$ after an 8-hour overnight fast.

\section{Discussion}

In chlorpropamide-pretreated healthy subjects and in patients with functioning islet cell tumors, administration of trichlormethiazide and diazoxide produced consistent and significant increases in blood levels of glucose. The present studies have produced evidence which indicates that changes in plasma levels of insulin are involved in mechanisms by which these compounds induce hyperglycemia.

In the healthy subjects in whom administration of trichlormethiazide and diazoxide produced consistent and significant increases in blood levels of glucose, there were no associated increases in plasma levels of insulin. Similar increases in blood glucose derived from exogenous or endogenous (glucagon) sources of glucose produced significant increases of plasma insulin. During the infusions of diazoxide on day 6 of the experiments, the increases in blood glucose were actually accompanied by decreases in plasma insulin. In one subject in whom multiple intravenous glucose tolerance tests were performed, glucose induced increases in plasma levels of insulin that were significantly diminished by prior administration of benzothiadiazines.

Administration of leucine to chlorpropamidepretreated subjects is a strong stimulus for insulin release and consequent hypoglycemia, as has been reported previously from this laboratory (14-16). This is demonstrated again by the data derived from the seven infusions of leucine before administration of benzothiadiazines (Table II,
Figure 1). After administration of the benzothiadiazine drugs, infusion of leucine caused lesser decreases in blood glucose in six, and lesser increases in plasma insulin in four, of the seven experiments. Thus, administration of these benzothiadiazines may inhibit the increases in plasma insulin that are evoked by administration of leucine to chlorpropamide-pretreated subjects. This stimulus to insulin release may be too potent under these circumstances to be inhibited consistently by the amounts of benzothiadiazine drugs administered.

In patients with insulin-secreting tumors of the pancreas, infusion of diazoxide after prior administration of trichlormethiazide caused prompt and significant decrease in plasma levels of insulin (Figures 2, 3; Table V). After infusion of diazoxide, increases in plasma insulin in response to intravenous administration of glucose were greatly reduced in comparison to the results obtained before administration of the drug (Figure 3; Table VI). Associated increases in blood glucose were greater after than before administration of the drugs.

More prolonged administration of the two benzothiadiazine drugs to patients with insulin-secreting tumors also caused clear-cut decreases in plasma levels of insulin, and these were associated with increases in levels of blood glucose into the normal or hyperglycemic range (Table IV).

Thus, when blood glucose was rising as a result of administration of trichlormethiazide and diazoxide to patients with islet cell tumors or to chlorpropamide-pretreated healthy subjects, plasma levels of insulin decreased or did not increase. In both groups of subjects the benzothiadiazine drugs inhibited the expected increases in plasma insulin after administration of glucose. In some healthy chlorpropamide-pretreated subjects benzothiadiazines inhibited leucine-induced increases in plasma insulin. In the patients with insulin-producing tumors, the drugs decreased fasting as well as postprandial plasma levels of insulin. All these findings can be interpreted to mean that trichlormethiazide and diazoxide decreased the secretion of insulin and inhibited insulin release in response to hyperglycemia. Only the finding of decreased levels of insulin in portal blood after administration of benzothiadiazines could furnish direct proof for such an effect in vivo. Nevertheless, our in- 
terpretation is strongly supported by the report of Frerichs and Creutzfeldt that diazoxide inhibits insulin release from pancreatic slices in vitro (20). The in vitro addition of benzothiadiazines to normal human serum to which tracer radioactive insulin was subsequently added produced no alteration in the distribution of radioactive insulin among the serum proteins, as demonstrated by electrophoresis (5). This can be taken as evidence against a possible alteration by benzothiadiazines in the character of circulating insulin.

Whereas our studies indicate that decreased insulin secretion, as well as failure of appropriate increases in insulin secretion, is involved in mechanisms by which trichlormethiazide and diazoxide induce hyperglycemia, they do not exclude additional mechanisms. Benzothiadiazines have been reported to contribute to hyperglycemia by effects that are exerted through extrapancreatic mechanisms. Thus, diazoxide has been shown to elicit a hyperglycemic effect in surgically depancreatized dogs (9).

The results of the present studies also indicate that trichlormethiazide and diazoxide have effects upon blood glucose that are not explained by alterations in plasma levels of insulin. In two experiments in chlorpropamide-pretreated healthy subjects, administration of leucine produced less hypoglycemia after administration of benzothiadiazines despite either the same or even larger increases in plasma insulin than when leucine was administered before administration of benzothiadiazines. These effects on blood glucose do not appear to be due to decreased sensitivity to endogenous insulin. Decreases in blood glucose after administration of exogenous insulin were not blunted in the two subjects in whom insulin tolerance tests were performed after administration of benzothiadiazines. Other investigators have also reported that benzothiadiazines do not impair sensitivity to insulin $(5,10,11)$. In some of the patients with functioning islet cell tumors, hyperglycemia followed acute or continued administration of benzothiadiazines, whereas plasma levels of insulin were still greatly elevated (Tables IV and V). It is thus apparent that important extrainsular blood sugar raising mechanisms are activated by these compounds.

In some experiments in chlorpropamide-pretreated healthy subjects blood glucose rose during the second infusion of diazoxide on day 7 of the experiments without any changes in plasma insulin (trichlormethiazide-diazoxide-saline series, Table II). In patient L.M. the fasting blood glucose level had risen to $127 \mathrm{mg}$ per $100 \mathrm{ml}$ the day after infusion of diazoxide, whereas it had decreased to 86 and $68 \mathrm{mg}$ per $100 \mathrm{ml}$ on the next 2 days. Plasma levels of insulin were depressed to the same extent on all 3 of these days after administration of the drug. These findings could also be interpreted as being due to extrapancreatic effects. On the other hand, small decreases or increases in pancreatic insulin release may not be reflected in peripheral plasma levels of insulin. Small increases in pancreatic insulin release sufficient to cause fasting hypoglycemia in patients with functioning pancreatic islet cell tumors may be reflected by elevated levels of insulin in portal blood at a time when normal levels are found in peripheral venous blood (21).

The mechanisms by which these benzothiadiazine drugs decrease the apparent secretory capacity of normal and pathologic pancreatic beta cells and increase blood glucose by extrapancreatic effects are not apparent from these studies. In experimental animals oral administration of large amounts of potassium salts together with oral administration of benzothiadiazines has decreased the magnitude of benzothiadiazine-induced hyperglycemia $(22,23)$. It has also been shown that potassium deficiency results in an exaggerated hyperglycemic response to diazoxide (11). In seven patients with chlorothiazide-induced glucose intolerance, supplements with $65 \mathrm{mEq}$ of potassium per day for 7 days were observed to reverse significantly the thiazide effect (24). In the present study levels of serum potassium were slightly lower after administration of trichlormethiazide than before its administration (trichlormethiazide is a natriuretic and kaluretic benzothiadiazine; diazoxide is not). When the experiments were repeated in two healthy subjects, this time giving $390 \mathrm{mEq}$ of potassium over a $49 \frac{1}{2}$-hour period concomitantly with benzothiadiazines, increases in blood glucose and lack of appropriate increases in plasma insulin were the same, even though serum levels of potassium were higher. In both subjects leucine-induced hypoglycemia was diminished to the same extent, and in one subject there was the same inhibition of insulin release after infu- 
sion of leucine as when benzothiadiazines were given without potassium. These experiments suggest that the effects of benzothiadiazines in these subjects were not related to hypokalemia or due to depletion of body potassium, but do not exclude more specific effects of benzothiadiazines on intracellular electrolyte metabolism.

It has been suggested that adrenergic influences may constitute a significant component of benzothiadiazine hyperglycemia $(9,11,25)$ and that potassium changes merely alter the sensitivity of sympathetic nerve elements or receptors (11). Increased release of catecholamines or increased catecholamine activity might explain part of the extrapancreatic hyperglycemic effect of this series of compounds. In addition, it has been reported that epinephrine may decrease release of insulin from the pancreatic islet cells, both in vitro (26) as well as in vivo (27). Thus, decreases in plasma insulin produced by benzothiadiazines may be due in part to increased release or activity of catecholamines. Since in the present studies depressed insulin levels persisted for at least 3 days after discontinuation of administration of benzothiadiazines to some of the patients with functioning islet cell tumors, other mechanisms may be involved. Also, diazoxide has been shown to have a direct effect upon insulin release from pancreatic slices in vitro (20). We have initiated studies to investigate the relation between possible changes in plasma and urinary levels of catecholamines and changes in levels of plasma insulin and blood glucose during administration of diazoxide to patients wtih functioning islet cell tumors. It seems significant, in view of the possible involvement of catecholamine activity in diazoxide hyperglycemia, that in organic hyperinsulinism the effects of benzothiadiazines are similar to those produced by administration of epinephrine, and that $1 \mathrm{mg}$ of epinephrine $\mathrm{HCl}$ given twice daily was capable of preventing any hypoglycemic episodes for consecutive days on a standard regimen in which two to four convulsive attacks (blood glucose 14 to 34 mg per $100 \mathrm{ml}$ ) had occurred daily during the preceding 11-day period (28).

Diazoxide has been used therapeutically to control severe hypoglycemic states. Drash and Wolff (29) first reported its use in a leucine-sensitive child with idiopathic hypoglycemia. In two patients with metastatic islet cell carcinoma, Bleicher,
Chowdhury, and Goldner (12) and Ernesti, Mitchell, Raben, and Gilboa (13) were able to prevent frequent severe hypoglycemic attacks by the combined oral administration of diazoxide and other benzothiadiazines. In our patient R.B., oral administration of diazoxide and trichlormethiazide permitted discontinuation of multiple nighttime feedings and uninterrupted sleep during a period of 3 weeks while the patient was awaiting surgery. These studies suggest that administration of these agents to patients with inoperable islet cell tumors is of value, in part by virtue of their depressing effects upon both fasting and postprandial hyperinsulinemia.

\section{Summary}

The effects of trichlormethiazide and diazoxide on plasma levels of immunoassayable insulin and blood levels of glucose have been evaluated in five chlorpropamide-pretreated healthy subjects before and after administration of leucine and in six patients with functioning islet cell tumors.

In the healthy subjects, the benzothiadiazine drugs produced elevations in blood glucose that were either associated with decreases or were not associated with increases in plasma insulin. Leucine-induced hypoglycemia and hyperinsulinemia were attenuated. The benzothiadiazine drugs did not decrease the hypoglycemic effect of exogenous insulin.

In the patients with insulin-producing pancreatic islet cell tumors, the benzothiadiazine drugs decreased hypoglycemia and hyperinsulinemia in the fasting state as well as postprandially. Glucoseinduced insulin release was greatly diminished.

These studies indicate that decreased insulin secretion as well as failure of appropriate increases in insulin secretion is involved in mechanisms by which trichlormethiazide and diazoxide induce hyperglycemia. They also suggest that these benzothiadiazines increase blood glucose by mechanisms that do not involve alterations in plasma insulin.

\section{Addendum}

Since completion of this manuscript, two studies have been presented in abstract form $(30,31)$ from which the authors also concluded that the hyperglycemic action of diazoxide is related, at least in part, to a decrease in insulin release. In a patient with unresectable islet cell carcinoma (31), oral administration of diazoxide had 
been used successfully for 11 months in preventing almost daily episodes of hypoglycemic convulsions or coma that had occurred before diazoxide administration.

We have administered trichlormethiazide and diazoxide to an additional five patients with insulin-secreting pancreatic islet cell adenomas. Acute or more prolonged administration of these compounds produced decreases in plasma insulin and increases in blood glucose similar to those described for our first six patients.

\section{References}

1. Fajans, S. S., J. C. Floyd, Jr., R. F. Knopf, J. Rull, E. Guntsche, and J. W. Conn. Evidence that decreased insulin secretion contributes to benzothiadiazine-induced hyperglycemia (abstract). Program of the 47 th Meeting of the Endocrine Society, New York, June 17-19, 1965, p. 66.

2. Wolff, F. W. Clinical and physiological implications of diabetes induced by benzothiadiazines. Diabetes 1964, 13, 203.

3. Dollery, C. T., B. L. Pentecost, and N. A. Samaan. Drug-induced diabetes. Lancet 1962, 2, 735.

4. Okun, R., R. P. Russell, and W. R. Wilson. Use of diazoxide with trichlormethiazide for hypertension. Arch. intern. Med. 1963, 112, 882.

5. Wolff, F. W., R. G. Langdon, B. H. Ruebner, C. Hollander, and R. D. Skoglund. A new form of experimental diabetes. Diabetes 1963, 12, 335.

6. Samaan, N., C. T. Dollery, and R. Fraser. Diabetogenic action of benzothiadiazines: serum-insulinlike activity in diabetes worsened or precipitated by thiazide diuretics. Lancet 1963, 2, 1244.

7. Wolff, F. W., and W. W. Parmley. Aetiological factors in benzothiadiazine hyperglycaemia. Lancet 1963, 2, 69.

8. Wolff, F. Diazoxide hyperglycaemia and its continued relief by tolbutamide. Lancet 1964, 1, 309.

9. Tabachnick, I. I. A., A. Gulbenkian, and F. Seidman. The effect of a benzothiadiazine, diazoxide, on carbohydrate metabolism. Diabetes 1964, 13, 408.

10. Chazan, J. A., and B. R. Boshell. Etiological factors in thiazide-induced or aggravated diabetes mellitus. Diabetes 1965, 14, 132.

11. Kvam, D. C., and H. C. Stanton. Studies on diazoxide hyperglycemia. Diabetes 1964, 13, 639.

12. Bleicher, S. J., F. Chowdhury, and M. G. Goldner. Thiazide therapy in hypoglycemia of metastatic insulinoma (abstract). Clin. Res. 1964, 12, 456.

13. Ernesti, M., M. Mitchell, M. S. Raben, and Y. Gilboa. Control of hypoglycaemia with diazoxide and human growth hormone. Lancet 1965, 1, 628.

14. Fajans, S. S., R. F. Knopf, J. C. Floyd, Jr., L. Power, and J. W. Conn. The experimental induction in man of sensitivity to leucine hypoglycemia. J. clin. Invest. 1963, 42, 216.
15. Floyd, J. C., Jr., S. S. Fajans, R. F. Knopf, and J. W. Conn. Evidence that insulin release is the mechanism for experimentally induced leucine hypoglycemia in man. J. clin. Invest. 1963, 42, 1714.

16. Floyd, J. C., Jr., S. S. Fajans, J. Rull, R. F. Knopf, M. M. Kirsh, and J. W. Conn. Direct evidence that leucine induces release of pancreatic insulin (abstract). Diabetes 1965, 14, 439.

17. Nelson, N. A photometric adaptation of the Somogyi method for the determination of glucose. J. biol. Chem. 1944, 153, 375.

18. Yalow, R. S., and S. A. Berson. Immunoassay of endogenous plasma insulin in man. J. clin. Invest. $1960,39,1157$.

19. Fajans, S. S., J. C. Floyd, Jr., R. F. Knopf, and J. W. Conn. A comparison of leucine- and acetoacetate-induced hypoglycemia in man. J. clin. Invest. 1964, 43, 2003.

20. Frerichs, H., and W. Creutzfeldt. Insulin release from pancreas of the rat, the rabbit and the miniature pig in vitro (abstract). Diabetologia 1965, 1, 80.

21. Floyd, J. C., Jr., S. S. Fajans, R. F. Knopf, and J. W. Conn. Plasma insulin in organic hyperinsulinism: comparative effects of tolbutamide, leucine and glucose. J. clin. Endocr. 1964, 24, 747.

22. Wolff, F. W., and W. W. Parmley. Further observations concerning the hyperglycemic activity of benzothiadiazines. Diabetes 1964, 13, 115.

23. Wolff, F. W., and R. G. Langdon. Conjoint clinic on drugs and diabetes. J. chron. Dis. 1964, 17, 585.

24. Rapoport, M. I., and H. F. Hurd. Thiazide-induced glucose intolerance treated with potassium. Arch. intern. Med. 1964, 113, 405.

25. Staquet, M., R. Yabo, J. Viktora, and F. Wolff. An adrenergic mechanism for hyperglycemia induced by diazoxide. Metabolism 1965, 14, 1000.

26. Coore, H. G., and P. J. Randle. Regulation of insulin secretion studied with pieces of rabbit pancreas incubated in vitro. Biochem. J. 1964, 93, 66.

27. Porte, D., Jr., A. Graber, T. Kuzuya, and R. H. Williams. Epinephrine inhibition of insulin release (abstract). J. clin. Invest. 1965, 44, 1087.

28. Conn, J. W., and E. S. Conn. Metabolism in organic hyperinsulinism. II. Effects of epinephrine on glycemic level and on combustion of carbohydrate. Arch. intern. Med. 1941, 68, 1105.

29. Drash, A., and F. Wolff. Drug therapy in leucinesensitive hypoglycemia. Metabolism 1964, 13, 487.

30. Seltzer, H. S., and E. W. Allen. Inhibition of insulin secretion in "diazoxide-diabetes" (abstract). Diabetes $1965,14,439$.

31. Graber, A. L., D. Porte, Jr., and R. H. Williams. Mechanism of diazoxide hyperglycemia (abstract). Diabetes 1965 , 14, 450. 